\title{
Lesson of the month: Oxycodone-induced leukoencephalopathy: a rare diagnosis
}

\author{
Authors: Eleanor Jones, ${ }^{\mathrm{A}}$ Udayaraj Umasankar, ${ }^{\mathrm{B}}$ Habeeba Mallu, ${ }^{\mathrm{C}}$ Timothy Hampton, ${ }^{\mathrm{D}}$ Angela Kulendran ${ }^{\mathrm{B}}$ and \\ Mehool Patel ${ }^{B}$
}

\begin{abstract}
Oxycodone-induced leukoencephalopathy is a rare diagnosis that should be considered in unconscious patients with appropriate history. We describe a case of a 57-year-old unconscious woman who required intubation and did not respond to naloxone infusion. The unconsciousness was initially thought to be due to hypoxic brain injury. However, a further review of brain imaging showed characteristic features of oxycodone-induced leukoencephalopathy. We describe the pathological and radiological features of this condition, and provide a concise review of the limited literature on this condition. Accurate diagnosis of this condition will be valuable to clinicians and patients in terms of their medium-term and long-term prognosis, and potential for rehabilitation.
\end{abstract}

KEYWORDS: Oxycodone leukoencephalopathy, cerebral white matter, toxic leukoencephalopathy, heroin, hypoxic brain injury

DOI: 10.7861/clinmed.2020-0650

\section{Case presentation}

A 57-year-old woman was found unresponsive at home. She had allegedly taken 14 tablets of $10 \mathrm{mg}$ oxycodone. She had type 2 diabetes mellitus, depression and panic attacks. She was only on mirtazapine. Her Glasgow coma score was 5/15 (E1V1M3) with hypoxia. She had renal and liver dysfunction. Urine toxicology screen was positive for opiates. An initial computed tomography (CT) of the brain was reported as normal. With a diagnosis of oxycodone overdose, she was intubated and given a naloxone infusion over 48 hours. CT of the brain 2 days later raised the possibility of global hypoxic brain injury. Over the next 10 days, she did not need sedation while intubated and ventilated, and had no gag reflex. In view of possible global hypoxic brain injury, organ donation was considered and spiritual care offered with the

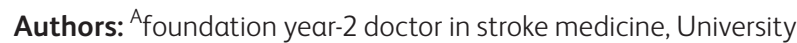
Hospital Lewisham, Lewisham, UK; ${ }^{B}$ consultant physician in geriatric and stroke medicine, University Hospital Lewisham, Lewisham, UK; ${ }^{C}$ foundation year-1 doctor in stroke medicine, University Hospital Lewisham, Lewisham, UK; ${ }^{\mathrm{D}}$ consultant neuroradiologist, University Hospital Lewisham, Lewisham, UK assumption that she was dying. Tracheostomy was performed 13 days later and she was stepped down to the stroke unit. Images reviewed by a neuroradiologist confirmed that findings were in keeping with oxycodone overdose. The initial CT showed low attenuation in both cerebellar white matter (WM) and globus pallidi (GPa). Subsequent imaging (Fig 1) showed progression of this low attenuation with pathologic mass effect resulting in tonsillar herniation and mechanical obstruction to cerebrospinal fluid outflow. An interval magnetic resonance imaging (MRI) of the brain showed appropriate evolution of the GPa and bi-cerebellar injury (Fig 2). The combination of cerebellar and GPa injury was suggestive of an acute oxycodone leukoencephalopathy rather than an inflammatory, metabolic or ischaemic insult. Electroencephalography was atypical for hypoxic ischaemic encephalopathy. She had a successful tracheostomy decannulation and percutaneous endoscopic gastrostomy insertion to maintain nutrition. Over the next 2 months she became more alert with significant neurological deficits and continues neurorehabilitation.

\section{Cerebral white matter}

The cerebral white matter (WM), with its myelinated axons arranged in tracts or fasciculi, occupies about half of an adult human brain volume with an estimated 100 billion neurones and 135,000 kilometres of axons, equivalent to running about thrice around the globe. With evolution, WM expanded disproportionately more than grey matter (GM) to transfer information rapidly between the distantly placed GM neuronal cell bodies. ${ }^{1}$ It has also been recognised that WM is found within the GM of the cortical mantle and subcortical nuclei (thalamus and basal ganglia).

\section{Toxic leukoencephalopathy}

Toxins that disrupt myelin sheath and/or axons include drugs of abuse (heroin and opioids); environmental factors (carbon monoxide), occupational factors (paint) or therapeutics (anti-neoplastic, antimicrobial and immunosuppressives)., 2,3 Interhemispheric and intrahemispheric pathways that serve cognition and emotion (neurobehaviour) are predominantly involved. Hence the most important clinical feature includes a change in mental status. ${ }^{3}$

The spectrum of neurobehavioural symptoms and corresponding pathology include mild (confusion or inattention; patchy intramyelinic oedema with preservation of myelin), moderate 


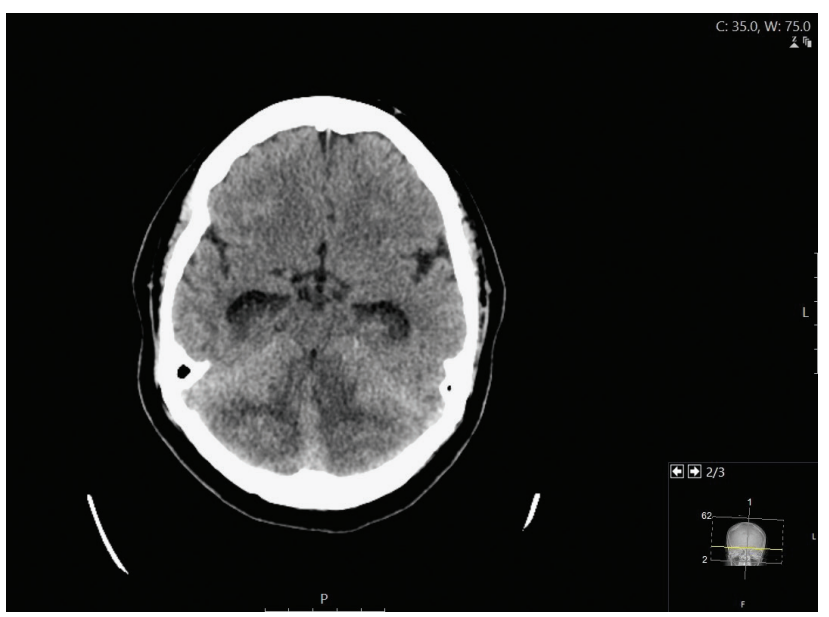

Fig 1. Computed tomography showing progression of low attenuation with pathologic mass effect resulting in tonsillar herniation and mechanical obstruction to cerebrospinal fluid outflow.

(apathy, somnolence or memory impairment; widespread oedema with demyelination but preserved axons) or severe (akinetic mutism, coma or death; axonal loss and oligodendrocyte
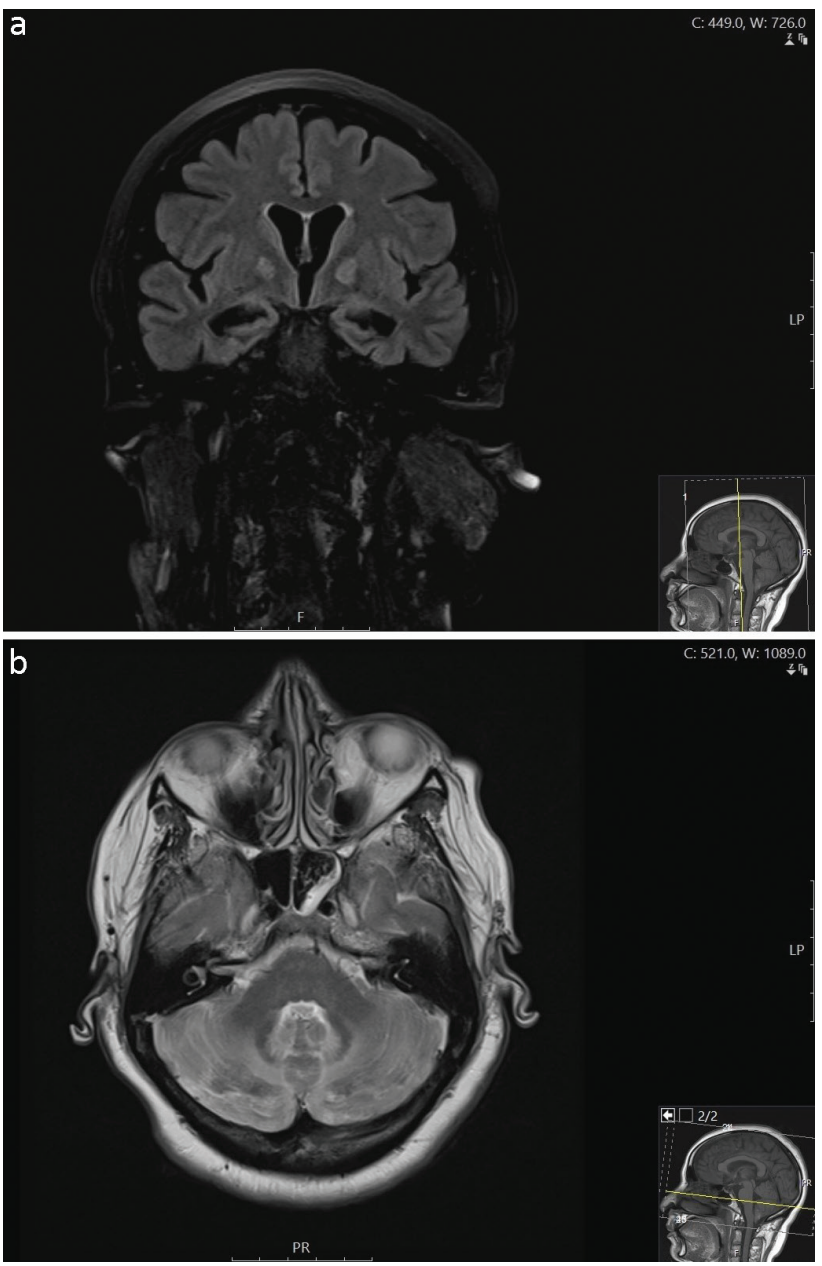

Fig 2. Interval magnetic resonance imaging of the brain showing appropriate evolution of the globus pallidi and bi-cerebellar injury. destruction). ${ }^{3}$ Other clinical presentations include acute cerebellitis, seizures, ataxia, dysarthria, catatonic state ${ }^{2}$.

\section{Oxycodone leukoencephalopathy}

Opioids are lipophilic and accumulate in the lipid-rich myelin sheath when taken in large doses. Oxycodone, a semi-synthetic strong prescription opioid, has an oral bioavailability of $87 \%$ (vs morphine at $30 \%$ ) and attains a maximum plasma concentration under 1 hour with a plasma half-life of 3-4 hours.

The first case series ( 47 patients) of inhaled heroin pyrolysateinduced WM damage was described in $1982 .{ }^{4}$ These patients presented with cerebellar syndrome and $\mathrm{CT}$ revealed hypoattenuation in cerebral and cerebellar WM. There are further reports of, predominantly, children presenting unconscious or unresponsive with WM changes in the cerebrum or cerebellum after inadvertent exposure to heroin, morphine or methadone. ${ }^{2}$ One Belgian case report was on a 65-year-old woman who had extensive, symmetrical cerebral WM changes after inadvertently ingesting a high dose of methadone. ${ }^{5}$

Oxycodone-associated neurotoxicity was first published in 2010. To the authors' knowledge, there are nine such cases reported in the literature (summarised in Table 1). ${ }^{2,6-11}$ These patients presented with varying symptoms. With opiate prescriptions on the rise, it is imperative to be aware of this clinical condition.

The hallmark of heroin-induced encephalopathy (along with morphine and methadone) is cerebellar involvement due to the affinity of heroin to ' $\mu$ ' receptors that are heavily distributed in the cerebellum. Oxycodone, however, has a high affinity for ' $\kappa$ ' receptors that are heavily distributed in the basal ganglia and cerebellum. $^{10}$

\section{Magnetic resonance imaging}

The WM involvement tends to be diffuse and symmetrical with characteristic vacuolisation and spongiform changes. ${ }^{3}$ Tormoehlen describes the classic MRI findings as symmetrical distribution in the cerebellar and posterior cerebral hemispheres, including the posterior limbs of the internal capsule. ${ }^{12}$ Cerebellar dentate nuclei, subcortical ' $U$ ' fibres in the posterior cerebrum and anterior limbs of the internal capsule are relatively spared.

The feature that is common to oxycodone neurotoxicity is GPa injury (Table 1). The involvement of basal ganglia has also been noticed in other case reports with methadone use. ${ }^{13-15}$ The bilateral symmetry and involvement of two regions (cerebellum and $\mathrm{GPa}$ ) are strongly suggestive of toxic damage. ${ }^{14}$ One has to be aware that GPa injury can also be seen in carbon monoxide poisoning and intravenous heroin abuse. ${ }^{16}$

A further analysis of MRI by Shrot and colleagues in three opioidrelated acute brain injury cases showed bilateral symmetrical cerebral WM and cerebellar lesions with involvement of putamen in two of these cases. ${ }^{17}$

\section{Conclusion}

Acute neurological presentation in patients 'being down' after drug overdose can be incorrectly attributed to hypoxic brain injury. Toxic leukoencephalopathy should be considered in the differential diagnosis. Diagnosis is often achieved with careful consideration of the history, clinical features and imaging findings. There is paucity of case reports on oxycodone leukoencephalopathy, hence the authors felt the need for reporting this case. 
Table 1. Case reports on oxycodone-induced leukoencephalopathy

\begin{tabular}{|c|c|c|c|c|}
\hline Author (year) & $\begin{array}{l}\text { Drug causing } \\
\text { encephalopathy }\end{array}$ & $\begin{array}{l}\text { Age and sex } \\
\text { Presenting clinical } \\
\text { feature }\end{array}$ & Brain structure(s) involved & $\begin{array}{l}\text { Outcome at time of } \\
\text { reporting }\end{array}$ \\
\hline $\begin{array}{l}\text { Morales Odia Y } \\
(2010)^{6}\end{array}$ & $\begin{array}{l}\text { Oxycodone } \\
350 \mathrm{mg} \text { and } \\
\text { oxycontin } 400 \mathrm{mg}\end{array}$ & $\begin{array}{l}46 \text { years } M \\
\text { Respiratory depression } \\
\text { and acute hydrocephalus }\end{array}$ & Cerebellum and $\mathrm{GPa}$ & $\begin{array}{l}\text { Survived with residual } \\
\text { disability }\end{array}$ \\
\hline Beatty CW $(2014)^{7}$ & Oxycodone $75 \mathrm{mg}$ & $\begin{array}{l}14 \text { years } \mathrm{F} \\
\text { Altered mental status and } \\
\text { decreased respiration }\end{array}$ & $\mathrm{GPa}$ & $\begin{array}{l}\text { Survived but with mild } \\
\text { disability }\end{array}$ \\
\hline Holyoak AL $(2014)^{8}$ & $\begin{array}{l}\text { Oxycodone and } \\
\text { clonazepam }\end{array}$ & $\begin{array}{l}26 \text { years } M \\
\text { Unresponsiveness }\end{array}$ & GPa and periventricular WM & $\begin{array}{l}\text { Tracheostomy; died of } \\
\text { another cause soon after }\end{array}$ \\
\hline $\begin{array}{l}\text { Ramirez-Zamora A } \\
(2015)^{9}\end{array}$ & Oxycodone & $\begin{array}{l}\text { Adult } \\
\text { Reduced sensorium }\end{array}$ & GPa and hippocampus & $\begin{array}{l}\text { Persistent neurobehavioral } \\
\text { symptoms }\end{array}$ \\
\hline \multirow[t]{3}{*}{$\begin{array}{l}\text { Middlebrooks EH } \\
(2017)^{10}\end{array}$} & $\begin{array}{l}\text { Oxycodone } \\
\text { (nasal) }\end{array}$ & $\begin{array}{l}29 \text { years } F \\
\text { Acute confusion, } \\
\text { bradykinesia and early } \\
\text { hydrocephalus }\end{array}$ & $\begin{array}{l}\text { Caudate, putamen, GPa, and } \\
\text { internal and external capsule }\end{array}$ & $\begin{array}{l}\text { Residual parkinsonism at } \\
\text { discharge }\end{array}$ \\
\hline & & $\begin{array}{l}52 \text { years } F \\
\text { Coma, AKI and } \\
\text { rhabdomyolysis }\end{array}$ & $\begin{array}{l}\text { WM of supratentorial brain and } \\
\text { right cerebellum }\end{array}$ & Died \\
\hline & & $\begin{array}{l}38 \text { years } M \\
\text { Unresponsiveness }\end{array}$ & $\begin{array}{l}\text { Periventricular WM, and sparing } \\
\text { of } B G \text { and posterior fossa }\end{array}$ & $\begin{array}{l}\text { Persistent incoordination and } \\
\text { weakness of all four limbs }\end{array}$ \\
\hline Duran D $(2017)^{11}$ & Oxycodone & $\begin{array}{l}10 \text { month F } \\
\text { Unresponsiveness }\end{array}$ & $\begin{array}{l}\text { Cerebellum and caudate } \\
\text { nucleus }\end{array}$ & $\begin{array}{l}\text { At } 33 \text { months had some } \\
\text { neurological signs }\end{array}$ \\
\hline Wheaton T $(2019)^{2}$ & Oxycodone & $\begin{array}{l}4 \text { years } \mathrm{M} \\
\text { Unresponsiveness }\end{array}$ & $\begin{array}{l}\text { Cerebellar and cerebral WM } \\
\text { lesions }\end{array}$ & $\begin{array}{l}\text { Survived with residual } \\
\text { disability }\end{array}$ \\
\hline
\end{tabular}

$\mathrm{AKI}=$ acute kidney injury; $\mathrm{BG}=$ basal ganglia; $\mathrm{F}=$ female; $\mathrm{GPa}=$ globus pallidi; $\mathrm{M}=$ male; $\mathrm{WM}=$ white matter.

\section{Conflicts of interest}

Dr Mehool Patel is on the editorial board of Clinical Medicine.

\section{References}

1 Zhang K, Sejnowski TJ. A universal scaling law between gray matter and white matter of cerebral cortex. Proceedings of the National Academy of Sciences 2000;97:5621-6.

2 Wheaton T, Toll B], Breznak K et al. Opioid-induced toxic leukoencephalopathy: A case report and review of the literature. Heliyon 2019;5:e03005.

3 Filley CM, Kleinschmidt-DeMasters BK. Toxic leukoencephalopathy. N Engl J Med 2001;345:425-32.

4 Wolters EC, Stam FC, Lousberg R] et al. Leucoencephalopathy after inhaling 'heroin' pyrolysate. Lancet 1982;320:1233-37.

5 Salgado RA, Jorens PG, Baar I et al. Methadone-induced toxic leukoencephalopathy: MR imaging and MR proton spectroscopy findings. AJNR Am J Neuroradiol 2010;31:565-6.

6 Morales Odia Y, Jinka M, Ziai MC. Severe leukoencephalopathy following acute oxycodone intoxication. Neurocrit Care 2010;13:93-7.

7 Beatty CW, Ko PR, Nixon J, Gospe SM Jr. Delayed-onset movement disorder and encephalopathy after oxycodone ingestion. Semin Pediatr Neurol 2014;21:160-5.

8 Holyoak AL, Trout M], White RP, Prematuranga S, Senthuran S. Toxic leukoencephalopathy in the intensive care unit. Anaesth Intensive Care 2014:42:782-8.

9 Ramirez-Zamora A, Ramani H, Pastena G. Bilateral pallidal and medial temporal lobe ischaemic lesions after opioid overdose. $J$ Neurol Neurosurg Psychiatry 2015;86:1383-4.
10 Middlebrooks AH. Acute neurologic toxicity related to nasal insufflation of crushed oxycodone: A case series and review of the literature. Neurographics 2017;7:36-41.

11 Duran D, Messina R, Beslow LA et al. Malignant cerebellar edema subsequent to accidental prescription opioid intoxication in children. Front Neurol 2017:8:362

12 Tormoehlen LM. Toxic leukoencephalopathies. Neurol Clin 2011;29: 591-605.

13 Corliss RF, Mandal R, Soriano BJ. Bilateral acute necrosis of the globi pallidi and rhabdomyolysis due to combined methadone and benzodiazepine toxicity. Am J Forensic Med Pathol 2013;34:1-4.

14 Corré ], Pillot J, Hilbert G. Methadone-induced toxic brain damage. Case Rep Radiol 2013;2013:602981.

15 Zanin A, Masiero S, Severino MS et al. A delayed methadone encephalopathy: clinical and neuroradiological findings. J Child Neurol 2010;25:748-51

16 Torres C, Zakhari N, Symons S, Nguyen TB. Imaging the unconscious 'found down' patient in the emergency department. Neuroimaging Clin N Am 2018;28:435-51.

17 Shrot S, Poretti A, Tucker EW, Soares BP, Huisman TAGM. Acute brain injury following illicit drug abuse in adolescent and young adult patients: spectrum of neuroimaging findings. Neuroradiol J 2017:30:144-50.

Address for correspondence: Dr Udayaraj Umasankar, University Hospital Lewisham, Lewisham and Greenwich NHS Trust, High Street, Lewisham, London SE13 6LH, UK. Email: udayaraj.umasankar@nhs.net 